LUCRATIVE ART OF DISASTER:

FETISHIZED APOCALYPSE,

CULTURE OF FEAR AND HURRICANE

"TAMMY" IN NATHANIEL RICH'S

ODdS AGAINST TOMORROW
Brno Studies in English

Volume 47, No. 1, 2021

ISSN 0524-6881 | e-ISSN 1805-0867

https://doi.org/10.5817/BSE2021-1-9

\title{
PARISA CHANGIZI
}

\begin{abstract}
With an eye to the visibly growing predilection for imagining humanity under siege in a rather disquietingly vulnerable state since Hiroshima's trauma up until the contemporary times, the present paper attempts to examine Nathaniel Rich's Odds Against Tomorrow (2013) through an ecological lens that takes fear as its central thematic concern with connection to the perception of (eco-)apocalypse. Ecological thinking, whether fictional or factual, seems to have been closely linked to the narratives of the future with an underlying Cassandran foreboding spirit. The narrativization of proleptically apocalyptic visions of human civilization, though drenched in fear and anxiety, essentially serves a survival-enhancing purpose. However, the over-zealous embrace of the catastrophic end-of-times prophecies seems paradoxically to have an adverse effect trapping us in a web of fear-induced paralysis, desensitization through repetitive exposure, and vulnerable susceptibility towards opportunistic maneuverings. Odds Against Tomorrow, dealing with the most common apocalyptic fears of the contemporary age, grapples profoundly with the wisdom (or lack thereof) of a culture alarmingly drenched in fear and acutely obsessed with risk-aversion.
\end{abstract}

Key words

(Eco-)apocalypse; fear; risk; climate change; survival

I don't want you to be hopeful. I want you to panic. Greta Thunberg (2019)

\section{Be Wary, Then. Best Safety Lies in Fear: Introduction}

In 1828, John Stuart Mill astutely noted that it is indeed de rigueur to be pessimistic about what lays ahead of us: "I have observed that not the man who hopes when others despair, but the man who despairs when others hope, is admired by a large class of persons as a sage" (290). Although Mill laments the disposition of "Every Silver Lining Has a Cloud" (Rich 2013: 95), our neurotic proclivity seems 


\section{Parisa Changizi}

to offer us an evolutionary advantage: "The cost of getting killed even once is enormously higher than the cost of responding to a hundred false alarms" (Nesse and Williams 1997: 6). Nathaniel Rich makes hay out of this readiness to fear and pessimism in his novel, Odds Against Tomorrow: "Wishful thinking," the protagonist of the story concludes, is indeed "negligent, dangerous" and potentially "homicidal" (Rich 2013: 97). In his novel, Rich highlights the "abyss of vulnerability" lurking beneath the surface of the ordinary, productive and functioning lives of "healthy agent bodies" that "can swallow every joy" at any given moment (Caputo 1993: 235). The grim amusement of total annihilation is what makes the story incipiently compelling to many readers. However, the novel gradually delves into a solemn inquiry into the nature of fear, age-old apocalyptic writings, contemporary noxious obsessions, and of course, climate change.

In Odds Against Tomorrow - set in New York, the ever-favorite apocalyptic metonym for the collapse of civilization - a young, brilliant mathematician called Mitchell Zukor, a present-day Nostradamus, calculates the risk of worst-case scenarios in the most intricate detail for FutureWorld, a company founded by an Alec "Charnoble," pun in all likelihood intended, that capitalizes on people's fear of possible yet not always probable future chaos, calamity and grief. FutureWorld offers "consulting services in "future prediction" (Rich 2013: 20). This private consulting firm "specialize in minimizing losses that may result from unforeseen or worst-case-imaginable scenarios" (Rich 2013: 21). However, most importantly, FutureWorld can indemnify any company against liability claims brought against them in the wake of a catastrophe (Rich 2013: 21). They protect their clients "against risks" and "lawsuits" (Rich 2013: 29) offering them "a get-out-of-jail-free card" (Rich 2013: 28). Therefore, by no means, the company is able to contain the potential disasters. What the company sells is the power to abnegate responsibility deviously solving the wrong problem while, thanks to Mitchell's scenarios, reassuring their clients that they have "good reason to be afraid" (Rich 2013: 108). The "natural-born terrorist," as Mitchell is described by Charnoble (Rich 2013: 111), teams up with Jane Eppler, an ambitious, educated woman who, in college, "had won an award for her senior essay on Antisthenes, the original Cynic," to sell fear to their rich clients (Rich 2013: 110). Mitchell is also fascinated by his college crush, Elsa Bruner, who suffers from a curious heart disorder that can kill her at any moment making her a microcosmic manifestation of our exceedingly terrorized world. Elsa and Mitchell keep correspondence while Mitchell sets out to become the prophet of doom, and Elsa starts out "a cooperative farm in Maine" (Rich 2013: 11), a project that ends "in disillusionment, pettiness, and, yes, violence" like many other historical "utopian communes or cooperative societies" (Rich 2013: 232).

At last, one of Mitchell's many doomsday predictions come to pass however on a much larger scale that he could have ever imagined. Although Mitchell has spent all of his life "trying to render catastrophe in calculable, precise dimensions," he finds himself "unprepared" when "a world-cleansing flood of biblical proportions, straight out of the preacher's sermon" hits New York City: "It [real catastrophe] was a form of genius. It astounded expectations, was unlike anything that came before" (Rich 2013: 154). Alongside many others, Mitchell is left to 
make sense out of the chaos of a "broken world" (Rich 2013: 265) and a "postapocalyptic wasteland" (Rich 2013: 272). What is perhaps uncannily prescient about the novel making it all the more intriguing is the fact that Rich was writing about Hurricane Tammy, the central (eco-)apocalyptic disaster of the story laying waste to New York City, just before a real-life hurricane, Sandy, inundated New York City and the Northeastern United States.

\section{And, Behold, I, Even I, do Bring a Flood of Waters upon the Earth, to Destroy All Flesh: (Eco-)Apocalyptic Writing}

Apocalyptic writing has an impressively long history, and of course, throughout years, has undergone changes. However, regardless of all the transformations, certain core elements of it have persisted. Norman Cohn argues that Jewish and Christian apocalypticism came out of ancient Persia, and were decisively shaped by the Zoroastrian original. He contends that the first great apocalyptic vision comes from Zoroaster whose prophecy tells of a coming consummation of history between the opposing forces of good and evil that is then followed by "the making wonderful" (1995: 29), the Zoroastrian utopia in which all that is imperfect will be replaced by a holy peace that will endure forever. Although apocalypse is widely associated with death, destruction, chaos, and carnage that purportedly presage the end of the world, the ugliness precedes regeneration. That is the cycle of death and rebirth most discernable in seasonal change, human life cycle, and of course the crucifixion and the Second Coming of Jesus making it a fundamental way we make sense out of the chaos of life. Interestingly, this often understated apocalypse's cyclical nature is also hinted at in the novel in a number of instances: Jane, Mitchell's colleague at FutureWorld, is optimistic that New York is "invincible," and it will find a way to "come back" after the Hurricane's total destruction of the city (Rich 2013: 195). Mitchell agrees with the cyclical nature of things on a much larger scale as, in the novel, the area near New York City's border is "about the end of the earth" (Rich 2013: 251): "The city will come back. This is temporary. Everything is temporary," Mitchell says (Rich 2013: 179).

As already partly discussed, in Judeo-Christian tradition, the term apocalypse itself "does not strictly mean catastrophe but, rather, revelation, that is, a book foretelling the end of times and revealing hope for a new age, albeit it a post-human age" (Northover 2016: 94). This concomitantly furious and hopeful spirit comes not only from the promise of a new age following the murder and mayhem, but also from the promise of justice being ultimately served. After the flood hits New York in the novel, Mitchell is prompted by Jane to contemplate whether what has happened to the city is "beautiful" or in fact "horrible" (Rich 2013: 191). Jane wonders "if the storm was so horrific, then why is everything now so beautiful?" (Rich 2013: 191) drawing Hurricane Tammy to the old-age concept of eschatological righting of vile injustices. Therefore, the basic elements of the apocalyptic writing can be summed up in the triad of "Destruction, Judgement and Regeneration" (Fortunati 1993: 83). ${ }^{1}$ The incentive behind the accentuation of the death and destruction component above all (to the point of equating 


\section{Parisa Changizi}

apocalypse with just a world-altering catastrophe) probably rises from humanity's inveterate fear of death and its obsession with immortality: "Fear is the oldest, most effective security system we have. So don't fear fear - embrace it," as Jane would pitch it to the company's potential clients (Rich 2013: 112). In fact, Frank Kermode, in his The Sense of an Ending, avers that apocalyptic thinking is deeply rooted in the "existential" anxiety that people feel about their own deaths (2000: 5). Apocalypse "lays bare deep-rooted, timeless fears: the fear of the powers of Nature; the fear of separation and loneliness; the fear of death" (Fortunati 2000: 83). However, what is the function of this type of writing that draws on our deepest fears, and seems to be at the height of its popularity in contemporary times?

Margaret Atwood, the Canadian speculative fiction writer and self-proclaimed environmentalist, might have an answer, though implicitly, to this inquiry. She defines the value of her craft, i.e. storytelling, from an evolutionary perspective. Storytelling is important because it warrants our survival as a species by the evolutionary advantage it provides us. In an article, entitled "Why Readers and Writers Are So Fixated with Dystopian Visions," for the Financial Times, Atwood (2014) asserts:

The genetic anthropologists would have it that we're hard-wired to be curious about what's around the next corner, since it might be a sabre-toothed tiger (danger) or a field greener than our own (food). Even memory, the brain folk are telling us, evolved not to help us recall the past, but to help us anticipate the future - it being more crucial to our survival - so we've been working on short-cuts to the future for millennia.

By telling stories, we are in fact passing on crucial information that can be used to increase our odds of survival. "Evolutionary theory," Atwood explains, "suggests that we are selected for storytelling in the Pleistocene: if you can tell the kids a story about how Fred got eaten by a crocodile, they don't have to discover the child-eating propensities of crocodiles first-hand, and may live to pass on their DNA." The stories give us the chance to "to choose between complex alternatives, and to act together to achieve a common goal" (2014). Analogously, Estok recognizes an increasing predilection for imagining ourselves "under siege and vulnerable" in twenty-first century (2013: 91). Quite in line with Atwood's suggestion, he interprets our endeavor at identification of the threats to our survival in hope of neutralization when we "narrativize our vision of apocalypse" as "a sign of our maturity as a species" (2013: 91): "Paranoia has its advantages," as Mitchell observes (Rich 2013: 252). In consonance with Atwood and Estok's arguments, the quote from David Goodis' Dark Passage, prefacing the third part of the novel, delineates the connection between fear, survival, and narrativization: "There's no such thing as courage. There's only fear. A fear of getting hurt and a fear of dying. That's why the human race has lasted so long" (qtd. in Rich 2013: 199).

In this sense, the fictional and real realms become all the more entangled. Fiction, especially the apocalyptic kind, as Jonathan Gottschall observes, is not indeed an escape from reality: "Our various fictional worlds are-on the wholehorrorscapes. Fiction may temporarily free us from our troubles, but it does so 
by ensnaring us in new sets of troubles-in imaginary worlds of struggle and stress and mortal woe" (2012: 49). Fiction gives us an invaluable opportunity to test possible scenarios without incurring any actual damage: "Fiction allows our brains to practice reacting to the kinds of challenges that are, and always were, most crucial to our success as a species" (2012: 67). Therefore, (eco-)apocalyptic stories graphically invoke the (eco)catastrophes of future to ponder the (environmental) crises of contemporary times. "Apocalyptic narratives," Sergio Fava explains, "do not foresee an abrupt end, a meaningless stop to a developing plot. They forebode a final outcome. As such, they are not self-contained independent narratives, but final, decisive chapters of comprehensive, all-encompassing narratives" (2013: 1). Therefore, the rhetoric of apocalypse, through building a bridge between the present actions and their future consequences ultimately could impose a poetics of responsibility on its readers. Gerry Canavan, in contrast to the postmodern skeptical disposition especially with regard to positive transformation, argues that "the radical disruption of history offered by eco-apocalypse is, in fact, a dialectical reassertion of both the possibility and the necessity of such change" (2012: 139). The presupposition of such cautionary tales is a conviction in humanity's capacity for repenting and mending its ways.

This very concomitant optimist and pessimist spirit might explain why the environmental discourse and apocalyptic narratives are no strangers to each other. In fact, appealing to the potent apocalyptic rhetoric as a strategy to awaken the public environmental consciousness is as old as the environmental movement in the United States if not older. Silent Spring (originally published in 1962), deemed widely to be a pivotal catalyzer of the American environmental movement and tapping into "public's growing uneasiness over science and the military in the Cold War era" (Killingsworth and Palmer 1996: 27), opens with a post eco-apocalyptic account, interestingly entitled "A Fable for Tomorrow," of a lost American idyllic rural town: "Then a strange blight crept over the area and everything began to change. Some evil spell had settled on the community: mysterious maladies swept the flocks of chickens; the cattle and sheep sickened and died. Everywhere was a shadow of death" (Carson 2002: 2). Lawrence Buell, in The Environmental Imagination, argues that "the metaphor of apocalypse" is "central to ecocentrism's projection of future of a civilization that refuses to transform itself" (1995: 285). "As ecocatastrophe," in other words, "becomes an increasingly greater possibility, so will the occasions for environmental apocalyptic expression and the likelihood that it will suffuse essay, fiction, film, sculpture, painting, theatre, and dance in unprecedentedly powerful, mind-haunting ways" (1995: 308). And this suffusion is indeed two-faced: it could be read as an inevitable tragic end or it can be a roadmap to what not to do.

\section{Our Fears do Make us Traitors: Fetishized Apocalypse}

"The threat to an ordered existence," Anthony Aveni writes, "lies at the root of all cosmologies" (2016: 40). Furthermore, apocalypse, Fortunati avers, "is such a brilliant metaphor for the human condition, it has proved to be an elastic, flexible 


\section{Parisa Changizi}

myth with a significance that has been continually modified in successive periods of history" (1993: 83). Although the Biblical schema is no longer considered to be the literal truth by many, "the modern, desacralised world is not exactly short of apocalyptic surrogates." The prospect of a nuclear war has receded since the collapse of the Soviet Union; however,

a more than adequate substitute for the position of Public Eschatology Number One has been found in the shape of imminent ecological catastrophe-greenhouse effect, global warming, ozone layer depletion, melting ice-caps et alia. There are, moreover, any number of alternative end-times scenarios including overpopulation, resource depletion, famine and pestilence (AIDS in particular), earthquakes, tidal waves, incoming meteorites, alien invasions and, depending upon which scientific theory one subscribes to, the sudden implosion, or gradual running down, of the universe. (Brown et al. 1996: 2)

The majority of studies into the origin of apocalyptic writings have developed over the past century. Writing in 1986, Hamilton Moore argues that the interest in the apocalyptic only briefly appeared at the turn of century thanks to the works done by scholars such as J. Weiss, A. Schweitzer, R.H. Charles, and F.C. Burkitt, and was mostly disregarded for decades up until its revival after the war (1986: 76). Biblical scholars and theologians not only neglected apocalyptic literature but even, in some cases, treated it with distain especially prior to mid-twentieth century. E. Frank Tupper explains that apocalypticism is "mostly an embarrassment to modern theology. Apocalyptic evokes images of the weird and menacing, the fantastic and grotesque, the ridiculous and the absurd. The label 'apocalyptic' has become a catchword for everything eschatologically illegitimate" (1975: 280). However, ever since Hiroshima and Nagasaki, Samuel Weber contends, "apocalypse is in fashion" (2015: ix). This phenomenon is evident in the number of literature that was put out in the decades following WWII. ${ }^{2}$ Beside the issues of WWII, the atomic bombs and the Cold War, apocalyptic studies, A.Y. Collins contends, flourished in the 1970s and early 1980s perhaps due to the "social and political upheavals of the 1960s and their effects" (2011: 447), and especially the Christian conservative reaction to the them. David Russell categorizes the whole period of twentieth century as an age of crisis politically, socially and religiously that called for resurfacing of apocalyptic writings in which anxious hopes and fears are expressed (1978: 5). As for the twenty-first century, September 11, the ongoing Terror War, violent conflicts in Middle East, frequent incidents of terrorism, 2008 global financial and mortgage crisis, the Gulf deep-water BP blowout, 2004 tsunami, Hurricane Katrina, Mayan Calendar's "Great Cycle” count coming to an end in 2012, COVID-19 pandemic, climate change and so on coupled with all too familiar narratives of different religious sects seeing these disasters as signifying the End of Days have exceedingly convinced people that the world as they know is on the verge of collapse. Based on our contemporary cultural manifestations, to use Wheeler W. Dixon's words, we seem quite "eager for the end" (2003: 2). It has been even proposed that "the nervous system of Modernity is rooted, so 
to speak, in a millenarian impatience with lingering ends" (Schwartz 2011: 176). And of course these ends come in different shapes and forms.

One probably major modern feature of apocalyptic writing is that, preponderantly, it is no longer a divinely inflicted catastrophe and rearrangement that humanity has to suffer through. Instead, the apocalypse is architected by the very capable hands of human race itself, or the very cruel and indifferent hands of nature that is in turn often manipulated by humanity. Nonetheless, the religious undertones persist. In the novel, when New York is going through a drought, the beloved weatherman on Channel 4 says that the Heavens are shut up because "people have sinned" (Rich 2013: 109). More central to the story, the deluge caused by Hurricane Tammy and the "Psycho Canoe" (Rich 2013: 99) in which Mitchell and Jane flee from the flooded Manhattan are manifestly reminiscent of the biblical flood and Noah's Ark. Another relatively more contemporaneous feature is that the overly fervid embrace of apocalypse has made a union with our angst about environmental despoliation and climate change in post-war years. Fairfield Osborn's Our Plundered Planet (1948), William Vogt's Road to Survival (1948), Rachel Carson's Silent Spring (1962), Paul Ehrlich's The Population Bomb (1968), Barry Commoner's The Closing Circle (1971), and Club of Rome's The Limits to Growth (1972) slowly but surely brought environmental concerns to the forefront of political and social landscape. Over the years, the anxiety about climate change, for example, has evolved to such a point that the American Psychological Association has issued a 70-page guide to battle the far-reaching effects of climate change on our psyche: "The health, economic, political, and environmental implications of climate change affect all of us. ... They induce stress, depression, and anxiety; strain social and community relationships; and have been linked to increases in aggression, violence, and crime" (2017: 4). Furthermore, it is averred in the guide that "the psychological responses to climate change, such as conflict avoidance, fatalism, fear, helplessness, and resignation are growing” (2017: 4).

In the light of such responses, one must wonder if we have fallen from a controlled sense of urgency through the looking glass into a world of madness and counter-productive panic. It seems that we do not need to contemplate for long to come up with reasons why the end is indubitably nigh: As Mitchell says, now it seems that it is always "a matter of death and death" (Rich 2013: 115). Nowadays we are inundated with an incessant trail of narratives of how the world and human civilization as we know is not far from obliteration: Natural resources are being depleted, polar ice caps are melting, North Korea's nuclear program is still a threat though decades-old East/West dynamic has collapsed, more than ever, in a post-September 11 world, hostile governments in Middle East and the terrorists are insatiably hungry for power, racism (along with all the other -isms, anti-s, and -phobias) and hate-crime is on the rise, now we have built-up resistance to antibiotics and the list goes on. More than ever, apocalypse is indeed in vogue, and not only in our literature and movie industry but also in our journalism: We are "bombarded by the ongoing doom-and-gloom of the daily news" (Siegel 2005: 1). And all of these environmental, political and social narratives are mutually reinforcing making each more robust on its own. The reason behind extreme reporting might be that, at the end of the day, we are awashed in dada, news from 


\section{Parisa Changizi}

an increasing number of directions compete to grab our attention. All these narratives and headlines have to be reported in the most shocking and terrorizing way tapping into our survival instinct to be perhaps worthy of our attention. Constant alerts and updates are designed specifically to be terrorizing to be arresting. This very imaginatively hyperbolic component, though not always fair or factual, is nevertheless part and parcel of apocalyptic writing. Due to its "proleptic nature," apocalypticism is inevitably entangled with our imagination as it foretells the (undesirable) future. Apocalypticism is as much as a genre "born out of crisis" as it is a venture that "produces crisis" as it has to imaginatively shape the undesirable realities into "proportions appropriate to the end of times" (Garrard 2012: 94).

However, the question is how much terror is too much especially with regard to the environment? Estok, in his "Terror and Ecophobia," argues that "terror," whether political or environmental, has laid siege to the twenty-first century imagination: "[W]ith the increasing perception of terror as the defining feature of our age there is an increasing inability to move beyond the dread and horror that frame our imagination" (2013: 95). He sees "structural similarities" between Al Qaeda and Katrina, human and natural assailants (2013: 96). Estok explains that the hostile human and natural events both defy set boundaries or any sense of predictability (2013: 93-95). He believes that such tone of urgency and crisis in representations of nature, especially in today's media, is highly counter-productive to environmentalism. Juxtaposing terrorist events such as 9/11 and its aftermath side by side devastating natural events such as Hurricane Katrina only perpetuates the detrimental myth that nature is an enemy to be fought and conquered quite similar to the terrifying terrorists. Therefore, our ecophobic tendencies are heightened when we are cajoled into subconsciously establishing a nexus between nature and the much despised terrorists as the dangerous Others at a time in history when we are most fascinated with apocalypticism and its concomitant violence, paranoia and moral dualism. Quite a similar point has been argued about the representation of climate change: "The rhetoric used in media coverage of the Cuban Missile Crisis," Alice Curry asserts, "has been shown to resemble that of current media speculations about climate change; political, media and social discourses engendered by the crisis envisaged an edge or brink as the final standpoint against planetary disaster" (2013: 23).

Complying with such an atmosphere of fear and impending (eco-)crisis in contemporary times, Odds Against Tomorrow opens with a description of probably three most prominent apocalyptic fears of the contemporary age: epidemics, elemental catastrophes, and (nuclear) wars. Mitchell, the protagonist of the novel, is revealed to have the most curious of fantasies: "The way other people fantasize about surprise inheritances, first-glance love, and endless white empyreal pastures, Mitchell dreamed of an erupting supervolcano that would bury North America under a foot of hot ash. He envisioned a nuclear exchange with China; a modern black plague; an asteroid tearing apart the crust of the earth, unleashing a new dark age" (Rich 2013: 3). Mitchell proves to be a true citizen of contemporary times and perhaps what the sociologist Ulrich Beck termed "risk society." Beck argues that the motivating force of the risk society can be expressed in the phrase "I am scared" (Beck 1989: 95). Similarly, for Mitchell, the core of his exist- 
ence can be encapsulated in one ostensibly modest question: "What should we be afraid of" while the sword of Damocles is eternally held over us? (Rich 2013: 3).

Mitchell has imprisoned himself in "a sublime realm of fantasy and chaos" where he dreams of "worst-case scenarios" that fill him with "real terror" though he claims otherwise (Rich 2013: 3). Generating " "prison conditions' within their psyches by fasting, by solitude, and similar procedures" is what mystics of all ages have been deliberately and voluntarily doing to store up the libido in the unconscious hoping it would erupt into a visionary and mystical experience (Edinger 1999: 16-17). Mitchell calls this perverse hobby of his "games of logic" that offers him "freedom;" however, his obsessive panic-ridden daily rituals of crisis calculations bring him nothing but misery (Rich 2013: 3). When an earthquake hits Seattle, in the midst of an atmosphere of "confusion" and "terror" where people are screaming, weeping, making odd uncontrolled noises, or being transfixed in their seats while the images of what has become of Seattle run on the screen before their eyes, the narrator admits that he feels that he is "eavesdropping on one of Mitchell's nightmares" (Rich 2013: 7-8). This is what Mitchell has to live through every day. To further underprop the weight of daily dose of persistent anxiety, "the images of atrocity" of "a naked child covered in ash, walking dazed through a mountain of rubble ... A convertible impaled on a spotlight. A dozen bodies running madly in every direction, silhouetted against a swelling wall of fire" and a dumb-strike reporter are juxtaposed with image of a fainted girl, Elsa Bruner, who we later on find out suffers from "BRUGADA," a heart disorder that can "strike you dead at any time. But otherwise you're completely healthy" (Rich 2013: 8-10). Mitchell concludes that Elsa is "a walking worst-case scenario" (Rich 2013: 11), and is befuddled how she is not weighted down by "the constant threat of annihilation" (Rich 2013: 36) perhaps as he is with regard to the world around him. The equation for Mitchell is most evident: The physical body is as unreliable as the physical world constantly threatening the survival of humanity.

\section{Responsibilities Abnegated}

Rich's description of Mitchell's life of assiduous worst-case scenarioism seems to showcase the modern life stripped down to its very core. Although creating a sense of urgency potentially can create the momentum to affect the necessary changes, are we overindulging in this rhetoric to a point of overturning its initial prudent objectives? Discussing the metamorphosis of apocalypse, Fortunati avers that apocalypse "is no longer feared; it is desired. It is no longer fought against; it is embraced. It has become a goal, an ambition, a means to fulfillment" (1993: 88). Why do we welcome imaginings of imminent destruction, environmental or otherwise, so ardently? The end is undoubtedly feared yet we curiously seek it in anticipation. The reasons behind such disposition are definitely multifaceted and potentially counter-productive:

And there is, after all, something comforting in the thought of imminent destruction. All bets are off, all duties executed, all responsibilities 


\section{Parisa Changizi}

abandoned. Contemplating not just one's own mortality, but that of an entire civilization, somehow makes the unthinkable not only palatable, but also vaguely reassuring. If no one will survive, who is to say that any of us ever existed at all? (Dixon 2003: 16)

Another reason why we revel in imagination of apocalyptic disasters could be that the prospect of a substantial change or at least tempering of our contemporary practices seems at best unpleasant to us. Slavoj Žižek, commenting on the failure of world powers to combat global warming in a meaningful way at the 2009 Copenhagen conference, discerns that more than ever, Feredrick Jameson's old quip holds true today: "[I]t is easier to imagine a total catastrophe which ends all life on earth than it is to imagine a real change in capitalist relations" (Žižek 2011: 334). Active and deep concern over the environment and climate change is closely related to how affluent and democratic a society is. However, such concept, especially when it comes to economy, have been heavily criticized: "The notion that environmental matters must be 'balanced' with economic ones is based on the false assumption that environmental concerns are a mere luxury" (Moore 2017: 13).

Interestingly, in the novel, what worries the top tenants of the buildings is not the "loss of life" that can be overcome eventually but the "loss of capital" that can bring "the chief executives to their knees" (Rich 2013: 14). We learn that the families of the earthquake victims enact the "uniquely American mourning ritual: they filled class action lawsuits" (Rich 2013: 14). When such atrocities happen, someone needs "to pay" (Rich 2013: 15). As Charnoble says, it is all about "Money. Money. Money-" (Rich 2013: 23). Before the flood, Charnoble, as Mitchell argues, exploits "fear to make money" at his company (Rich 2013: 151). After the flood, Jane becomes the next Charnoble. Tearing himself apart from the business of fear, Mitchell leaves the flooded New York to live in wilderness all by himself except for the monthly visits from Jane. The "intoxicating" appeal of the "sprawling, chaotic, giddy" way of life in the Flatlands arrests the imagination of Jane in contrast to her "armored limousine" and its "refrigerated air" (Rich 2013: 305). At that moment, she does not even care that Ticonderoga, the utopian commune in which Elsa lived, was a failure, or that these people are cheating as FutureDays, the new company Jane founded after the flood, is providing them with the "essentials" to survive. She just feels that she wants to "live in the Flatlands rather desperately" (Rich 2013: 305-306). The "monthly ritual" of exchanging of "heels" to "boots" to go to "the wilderness" has almost worked its magic on her (Rich 2013: 297). However, she remembers that a "fortune is at stake" back home, and that's when she asks her driver to take her back to the city (Rich 2013: 306): "It is difficult to get a man to understand something," as Upton Sinclair astutely observes, "when his salary depends upon his not understanding it!" (1994: 109).

Furthermore, there does not seem to be the necessary impetus to slaughter an economy that has lifted millions of people out of poverty, as some have argued, for good reason. Dougald Hine and Paul Kingsnorth's "Dark Mountain Project" (2009) came out of their reluctant acceptance of the fact that the environmental activism is not going to stop the devastation of natural world by the human ma- 
chine after all: "Everything was disintegrating, yet here was man, the poor schlemiel, running around with his glue and his tape" (Rich 2013: 236). Bjørn Lomborg (2019), in "It's Cheaper to Talk than to Cut Emissions," argues that although "the UK parliament declared that the planet is facing a "climate emergency," the "German government prioritizes climate action so highly that it convened a "climate cabinet," and "[c]utting CO2 emissions to net zero by 2050 or much sooner" has been endorsed by 2020 Democrat presidential candidates in USA, "Britons are unwilling to cut their driving, flying, and meat consumption significantly in order to combat climate change," only "one-third of Germans support a controversial proposed tax to reduce global warming," and "[m]ost Americans ... are willing to pay up to $\$ 200$ per year to fight climate change." No matter how misleadingly romantic the idea of returning to something similar to pre-modern times is, it does not seem that people are willing to surrender all the advantages and conveniences of a post-industrial capitalist system.

\section{Having Just Too Much/Nothing to Lose}

Perhaps another reason why we are preoccupied with the idea of apocalypse more than ever is that now, after years of progress, we feel we just have too much to lose. That certainly can explain why Rich has chosen New York as the setting of his novel. E.B. White, in his 1949 essay-turned-book, Here is New York, following his celebration of the city's magnificent multicultural character and urban sprawl, talks about the ironic vulnerability of a city that has now everything to lose:

The city, for the first time in its long history, is destructible. A single flight of planes no bigger than a wedge of geese can quickly end this island fantasy, burn the towers, crumble the bridges, turn the underground passages into lethal chambers, cremate the millions. The intimation of mortality is part of New York now: in the sound of jets overhead, in the black headlines of the latest edition. All dwellers in cities must live with the stubborn fact of annihilation; in New York the fact is somewhat more concentrated because of the concentration of the city itself, and because, of all targets, New York has a certain clear priority. In the mind of whatever perverted dreamer might loose the lightning, New York must hold a steady, irresistible charm. (54)

The Empire state building, in a post 9/11 world, the narrator explains, "was the most disaster-prone building in America. It had to be evacuated nearly once a year-for no-fly-zone infractions, bomb threats, tropical storms, and blackouts" (Rich 2013: 13). Mitchell wonders about his end: "I work in the tallest building in the biggest city in the richest country in the world. So what's my future? Annihilation?" (Rich 2013: 20). The same can apply to human civilization especially as New York has come to represent it all. Rich himself begins his novel by a quotation from Saul Bellow's Mr. Sammler's Planet equating New York to the whole of civilization: "New York makes one think about the collapse of civilization, about Sodom and 


\section{Parisa Changizi}

Gomorrah, the end of the world. The end wouldn't come as a surprise here. Many people already bank on it" (qtd. in Rich 2013: 1). The more we have in terms of luxury, convenience and prosperity, the more, it seems, we are afraid to lose it all. Furthermore, the spectacle of a towering Metropolis falling is just too entertaining to be passed over: New York is the modern-day Pompeii and Babylon.

That being said, being cognizant of how far we have come does not mean that we are oblivious of the truly dark passages of our history: "There is no document of civilization which is not at the same time a document of barbarism," as Walter Benjamin most aptly puts it (1969: 256). Relishing in the idea of total annihilation of the world can arise from the sort of self-hatred or rather the desire for self-immolation that is willing to surrender the whole of human existence along with centuries of art, literature, scientific achievement if it means that finally the accompanying atrocities and inequalities will be evaporated too: "What makes this appealing is the thought that if none shall survive, then, at last, all class, social, and racial boundaries will have been erased. No more slavery, no more sweatshops, no more prejudice, and no more inequality. ... We are all, thus, equal in death" (Dixon 2003: 18). Such extremist views and anti-humanism have more credence among us that we probably would like to believe. Dave Foreman, the American environmentalist and co-founder of the radical environmental advocacy group Earth First!, along with many other radical Greens, believes that humanity is a cancer on nature.

Quite in line with such disposition, the good that can come out of human tragedy is hinted at in the novel. After the flood, the earth is shown to have been released from its human slaveholders: "That was another result of the flood and its destruction: it had not only wiped clean the ground, it had also expanded the sky. It used to steal through the narrow slivers between skyscrapers, a petty thief; now it had been restored its dominion. It was radiant with its pride" (Rich 2013: 292). The hurricane introduces a radical rupture to the civilized world of New York. The natural world gets a come-back only after the human dwelling is destroyed by the hurricane. Earth's resilience and adaptability against anthropogenic manipulation is hopeful on one front. However, in effect it essentially showcases humanity's expendability. In post-apocalyptic rhetoric, "the potential for human embeddedness within nature is already seriously if not irreparably compromised" (Curry 2013: 20). Furthermore, a twisted take of it might, on one hand, sanction any human manipulation as the Earth will sort out everything at the end after all, or on the other hand, incite self-harm/eradication in hopes of salvaging what's left of the planet. Recognition of culpability and onus seems necessary to encourage change; however, a suicidal, self-hating civilization who sees itself as a plague on this planet cannot be the answer to the problems we are facing in contemporary times.

\section{Fertile Soil for Manipulation}

The fear-mongering tactic, long abused by politicians, can also render us more susceptible towards opportunistic maneuverings. This is exactly what the Amer- 
ican sociologist Barry Glassner, and the American physician Marc Siegel argue respectively in their books The Culture of Fear: Why Americans Are Afraid of the Wrong Things (2000), and False Alarm: The Truth about the Epidemic of Fear (2005). Manipulation of our perception of risk and danger wins elections for politicians, raises money for advocacy groups, and garners rating for TV shows and so forth all the while all statistics show that we are indeed, by all accounts, living in a much safer and healthier world. As Jane argues, "devising worst-case scenarios," and scaring people is a "talent" (Rich 2013: 205). In such a uniquely panic-ridden environment, surely the risk-obsessed Mitchell is destined to achieve greatness albeit to his own demise: "Risk was all that interested him; it was all he wanted to do. Really it was all he could do" (Rich 2013: 18). After the flood, Jane feels compelled to capitalize on the human misery replacing her former boss. She contends, " $[t]$ he more uncertainty, the higher the stakes - Future Days will only get bigger and bigger. Futurism is the way" (Rich 2013: 235).

In fact, Charnoble built his unique insurance company upon the back of such risk-obsessed, panic-ridden, and confused atmosphere. Beck, in his World at Risk, puts forth his idea of "insurance principle" which asserts "the absence of adequate private insurance protection is the institutional indicator of the transition to the uncontrollable risk society of the second modernity" (2009: 132). Here, he tries to draw a line between the risks of the first modernity which can be managed by taking out an insurance policy and the risks of the second modernity (such as radioactivity, terror, genetic modification, financial crises) that no insurance policy would contain them. Furthermore, commenting on the selective non-coverage practice of private insurance companies, Beck adds, the "economic calculations of the insurance industry can be made the chief witness for a politically charged practice: the bigger the threat, the more limited the private insurance protection" (2009: 133). That is precisely why the business leaders of Seattle are outraged about the lawsuits after the earthquake:

How could they have foreseen the horrors that had engulfed their city? How could they have known that the Emerald City Tower would compress like an accordion or that the black windows that sheathed the seventy-six-story Columbia Center would shatter like a mirror? Sure, they understood the general threat. ... They knew nothing about seismology. They were masters of industry, not masters of the universe. (Rich 2013: 14-15).

People now demand to convert blood into treasure; however, the exchange rates are not in favor of business leaders: "That's because the insurance industry, after the terrorist attacks at the turn of the century, had discontinued major catastrophe coverage. The corporations' insurance plans were worthless. This was a catastrophe in itself" (Rich 2013: 15). And this is exactly where Charnoble enters with his exceptional scheme and his unique insurance company to protect the corporations. 


\section{Parisa Changizi}

\section{Normalizing the Abnormal}

Another paradoxically adverse effect of over-zealous embrace of the catastrophic end-of-times prophecies seems to be that apocalypse is normalized, and people are desensitized toward its implications. What used to be unthinkable now is commonplace. Frederick Buell, in From Apocalypse to Way of Life, contends "in internalizing environmental crisis so completely, contemporary literature represents it more and more as a regular and unavoidable feature of daily life - as a context society now dwells in, not a future to be feared" (2003: 261). He also maintains "crisis seems increasingly a feature of present normality, not an imminent, radical rupture of it" (2003: 163). And that exactly would describe the life of Mitchell. On the other hand, it can be argued that such over-emphasis can trap us in a web of fear-induced paralysis. This point is exactly in line with the reaction of a group of people after the disaster hits in the novel:

But a third group, whether out of ignorance or pure panic, would have stayed put. That, after all, was the natural human response to disaster. Psychologists called it the incredulity response, or normalcy bias: most people, having never experienced a real catastrophe firsthand, don't actually believe their eyes. This is why some pleasure cruisers don't leave their cabins even as their ship is sinking, why some office workers continue sending emails even after they've learned that, on a lower floor, their building is on fire, why a stunningly high percentage of people who die in skydiving accidents are found to have never pulled the backup parachute line. The people waiting in the trains needn't have waited very long. In the tunnels the pipes would have soon burst, and with the pumps overwhelmed, the water would have risen quickly from the ground. (Rich 2013, 174)

\section{Broken Trust}

Furthermore, as many of the predictions made by these so-called prophets of doom turn out to be false, the credibility of such predictions becomes dubious: "It is all too easy to ridicule doom prophets, chiefly because they are always wrong" (Joyce 2018: 37). The prophesies of Paul Ehrlich, Al Gore, and many others about future environmental catastrophes were not fulfilled at their projected dates. However, that is not to say that all of these prophets are insincere charlatans. Some even go as far as arguing that their aim is not "to predict the future but to change it" shifting the value of their writings from scientific to political (Killingsworth and Palmer 1996: 41). The reason why Mitchell is the best guy to capitalize on the fear of the people is that he is not interested in risk for purely financial reasons like Charnoble. His fear is "real, hot, and viral" (Rich 2013: 25). His eyes "communicate urgency. Urgency, and even fear - fear of a great danger coming on," a quality Charnoble cannot imitate regardless of practice (Rich 2013: 31). Mitchell's sincerity is exactly what Charnoble needs as for people who are in the business of fear, it is essential for them to be able "to frighten clients. To 
convey a sense of implacable doom" (Rich 2013: 31). The problem with this type of predictions, especially when it comes to the environment and climate, is the complexity and unpredictability of the systems with which they are working. To make this point clearer, we need to look at the science and mathematical calculations behind these predictions.

Building his argument on the example of John Napier of Merchiston (15501617) who predicted "the day of the End in his exegesis of the Book of Revelation," Fava assumes a relation between mathematical prediction and apocalypticism. He explains that "quantification was supremely important in the formalisation and universalization of apocalyptic expectations, eliminating its geocultural markers, numerologically or mathematically justifying universal applicability of context-specific narratives" (2013: 5). Fava furthermore explains the problems that could arise when using mathematical computer simulations to predict the future when it comes to climate change: "(a) working with the complex, infinitesimal, potentially intractable or unknown connections between causes and consequences; (b) making a convincing - yet neutral, non-value laden - argument for global, pervasive adaptive change based on a hyper-complex causality chain" (2013: 6). At the end of the day, regardless of the talk of alleged "Consensus" among Scientific Community, the issue of Climate Change proves to be quite complicated to be settled accurately once and for all. As Antonia Mehnert explains,

While the IPCC states in its 2007 Synthesis Report that "the warming of the climate system is unequivocal" (30), it cannot say anything about its causes or impacts with absolute certainty. In order to make any knowledge claims, the IPCC then uses a variety of epistemic modifiers such as "very likely" (>90\%), "unlikely" (<33\%), or "high or medium confidence," but its method of presenting the research results clearly illustrates that science is not a discipline that aims at "being settled." (2016: 130)

In the novel, Mitchell himself is a "mathematical zealot" who is obsessed with legendary statisticians and mathematicians such as C. R. Rao, Leonardo Fibonacci, Andrei Nikolaevich Kolmogorov, and Peter L. Bernstein (Rich 2013: 4). After Hurricane Tammy hits New York, Mitchell becomes a "national celebrity" and a "prophet" overnight, and is asked to prophesize what will "happen next" to "New York, to America, to the world" (Rich 2013: 210). People are aghast how the prophesies of Cassandran Mitchell could have gone unheard. In Greek mythology, the prophetess, Cassandra, was granted the power to foretell the future by Apollo who loved her. However, as she rejected his love afterwards, he cursed her: "[A]lthough he could not take back his gift - divine favors once bestowed might not be revoked - he made it of no account: no one ever believed her. ...It was her fate always to know the disaster that was coming and be unable to avert it" (Hamilton 1942: 292). The archetype of Cassandra persisted through culture, and found its way into the environmental discourse to preach vigilance lest the ever-increasing foreboding environmental predictions be turned into unheard Cassandra's cries. Alan AtKisson, in 1999, contends that humanity is caught in the "Cassandra's dilemma" as warnings about future environmental catastrophe 


\section{Parisa Changizi}

abound; however, the message is not getting across to the majority of people: "[T] oo often we watch helplessly, as Cassandra did, while the soldiers emerge from the Trojan horse just as foreseen and wreak their predicted havoc. Worse, Cassandra's dilemma has seemed to grow more inescapable even as the chorus of Cassandras has grown larger" (30).

As true as the sentiment may be, we have come a long way from 1999. The late 2010s is the time of sixteen-year-old Swedish environmentalist teenager with Asperger (according to her twitter bio), Greta Thunberg, who gets nominated for a Nobel Peace Prize for "her tireless work combating global warming" (Vagianos 2019). Now is the time of the "Extinction Rebellion" occupying prominent sites in central London to rally international support around a common sense of urgency to tackle climate breakdown (Farand 2018). Now is the age of extreme reactions to environmental destruction from "polymorphous" and "pollen-amorous" ecosexuals who aspire to "create a more mutual and sustainable relationship with the Earth" by taking the Earth as their "lover" (Stephens and Sprinkle) to the New Zealand Christchurch mosque shooter who describes himself in his manifesto, entitled "The Great Replacement," as an "eco-fascist" (Weissmann 2019) to individuals such as an Oxford Professor, Dr. Young-hae Chi, who contends that aliens are interbreeding with humans to create a new hybrid species as "a response to ... [the] impending demise of human civilization," due to climate change and nuclear weapons (Yedroudj 2019). If anything, now is the time of too many terrifying loud doomsday voices competing for the cup of the most horrific of them all.

Quite in line with such more contemporaneous attitudes, although people claim that Mitchell's "prophesies" went unheard, he is not exactly the Cassandra of New York (Rich 2013: 3): "It's been written that Mitchell saw it coming, Seattle - that he tried to tell the world, but no one would listen to him. This, I feel confident insisting, is pure mythology. Mitchell was prepared for disaster, sure, but he had no better idea than anyone else what was going to unfold that Tuesday. I know because I was with him" (Rich 2013: 5). Towards the end of the novel, Mitchell purportedly metamorphoses to yet another "prophet." Jane tells people at the office that Mitchell now looks "the part of a mad old oracle" like "Tiresias himself, frail and muttering and blind" (Rich 2013: 294). However, he is neither frail nor blind: "Mitchell wasn't frail. Far from it, in fact, he was broader in his shoulders and neck-his body, in a state of shock, frantically adding muscle to cope with the intense physical exertions it had been forced to endure for the first time in its existence. And Mitchell wasn't blind either, except in one respect: he had no idea what he looked like" as he has no mirror (Rich 2013: 294-295). The truth of the matter is that Mitchell is no prophet; in fact, he is just a man who is drowning in a bottomless sea of worst-case scenarios. One of his countless scenarios is bound to be fulfilled at some point. This astutely reflects the contemporary world in which the ever-growing and often miscalculated possibilities of apocalyptic futures enjoy more credence than the more limited thought-through probable scenarios. 


\section{The Real Tragedy of Life Is When Men Are Afraid of the Light: Response to (Eco-)Apocalypse}

In Odds Against Tomorrow, the immediate response to disaster is not overwhelmingly graceful, and the redemptive agency given to characters subsequently is quite limited. Homo sapiens, in Latin, literally means "wise man." The question is that how wise of a species we are in face of environmental catastrophe? After the flood hits, the all-too-familiar barbarism after the collapse of civilization, here due to environmental reasons, is put on display. As Jane observes, since Tammy, the walls have been "collapsing in on themselves." Mitchell then draws Jane's attention toward the "the impatient refugees still standing in line, at the Watkinses screaming at their children, who were stealing one another's burritos. 'This is a disaster waiting to happen" (Rich 2013: 260). After Tammy, the confusion, capriciousness, and quick-to-violence tendencies of humanity is best exposed when Mitchell is exalted as a hero one second, and demoted to a villain the next moment: "At lunch, two of the McIntyre kids had even asked him to autograph their napkins. But now the mood was different. Nobody here wanted his ink. They wanted his blood" (Rich 2013: 247). And when people move past the initial violent phase, things do not necessarily get better. Writing in 1997, Daniel Wojcik notices a new trend in apocalyptic narratives that evades a hopeful outcome:

Until recently, the end of the world has been interpreted as a meaningful, transformative, and supernatural event, involving the annihilation and renewal of the earth by deities or divine forces. During the last half of the twentieth century, however, widespread beliefs about a meaningless apocalypse have emerged and now compete with traditional religious apocalyptic worldviews. (1)

From an apocalyptic narrative, at least in a more traditional framework, one might expect a sense of regeneration especially when water (or deluge) is the source of catastrophe. Carl Jung explains that the "maternal significance of water ... is one of the clearest interpretations of symbols in the whole field of mythology, so that even the ancient Greeks could say that "the sea is the symbol of generation.' From water comes life” (1976: 319). "Breaking up all forms," Mircea Eliade contends, "doing away with the past, water possesses this power of purifying, of regenerating, of giving new birth. ... Water purifies and regenerates because it nullifies the past, and restores - even if only for a moment - the integrity of the dawn of things" (qtd. in Douglas 1966: 162). However, the cathartic, regenerative significance of apocalypse and the flood is at best dubious in the novel making the story all the more a child begotten of its times. Mitchell eventually decides to leave New York and goes to the wilderness. However, his journey and subsequent settlement do not truly vociferate redemptive solution to contemporary malaises. One of the first decisions he makes in the wilderness is to submerge himself in the creek he encounters there. The baptismal water of the creek is supposed to be life-affirming and purifying. At first, we are presented with an image that seems to asseverate the long-established symbolism: 


\section{Parisa Changizi}

He removed his sneakers and waded in, the mud slimy beneath his feet, until the water rose to his armpits. The creek was rust colored, silty, and very cold. Without thinking, without caring, he dunked his head. The water flooded his ears, tickled his face, cradled his brain. The coldness was shocking, but when he resurfaced, everything had sharpened. The whiteness of the sky, the marsh's clicking insect choruses, the breeze against his face like a fresh shave. (Rich 2013: 281-282)

However, the common reaction for a twenty-first century individual is to be emphatically conscious of the risk any contact with the water in the creek can potentially present rather than succumbing unswervingly to its magical properties. Mitchell reckons he should applaud himself for not bothering himself about the consequences: "On the way back to the bank building he congratulated himself for not worrying about the toxins that might have tainted his little bath - mercury, PCBs, dioxins, sewage" (Rich 2013: 282).

Mitchell's plans of settlement in the wilderness is riddled with problems and contradictions. Mitchell almost completely recedes into isolation; Jane being the only departure from the self-imposed insulation from the human world. He is in desperate pursuit of Elsa Bruner's "ideal scenario" which is a "self-reliant, sovereign, irreproachable" existence (Rich 2013: 289) although he knows that "Elsa's fantasy had been overrun by the actual world and its desperate hordes," (Rich 2013: 232) that is to say, "the twin blows of Brugada and Tammy" (Rich 2013: 280). He wants his residence to be "an impregnable, self-contained, self-sustaining fortress" (Rich 2013: 289). The ultimate resolve of the walls of this fortress, however, is to keep everything and everyone out: "It was attached to a cracked window frame, one of the thousands of pieces of debris that formed the wall to Mitchell's fortress, nearly every component with rough surfaces and jagged edges. You couldn't climb a wall like that-you couldn't even touch it. That seemed to be the point" (Rich 2013: 297-298). His initial plan in fact has a whiff of ecophobia demarcating the human in nature as a superior, solo, and in danger entity. He feels besieged all around by rats, foxes, opossums, raccoons, and owls: "Yes, it would be important to build the wall high. At least to the height of a tall human being. It was impossible to know what was lurking in this wilderness-or who" (Rich 2013: 279).

Moreover, Mitchell, in his voluntary (semi-)isolation smelling like a "wild animal" in the "crazy hobo territory" (Rich 2013: 300), as Jane puts it, not quite unlike the celebrated literary figure and proto-environmentalist Thoreau, still holds ties to the outside world although he set out to be completely "self-reliant." He gives Jane an "envelope containing his monthly update to his parents and his supplies list for the following month" when she comes to visit him (Rich 2013: 303). Furthermore, as Jane reckons, he has not lost his "power of divination" yet as he assesses the "recovery" process for her though she always keeps a vigilant eye for "signs of impending madness" (Rich 2013: 299-300). He even proffers her a new slogan: "Future Days: because the future is not quite what it used to be" (Rich 2013: 303-304). Therefore, deep down, he is the same brilliant, obsessive Mitchell with his papers and calculator; however, now the spirit of his appraisals 
is more buoyant: "It could not look more different from his FutureWorld office. This room felt lived-in, thought-in, alive with knowledge. At FutureWorld the offices had felt choked by knowledge-choked to death" (Rich 2013: 296). His initial aspiration was indeed to abjure "the whole tangled cycle of anxiety and fear and paranoia" of his past life, and direct his "teeming energies," or rather "fanaticism," towards working "in the fields, building-shaping-making-growing-spreading" (Rich 2013: 289). The application of his obsession "based in mathematics and logic, even scenario planning and risk analysis" is now "practical instead of theoretical" (Rich 2013: 287). Obsession gives Mitchell's life a sense of purpose. $\mathrm{He}$ admits that without obsession he has "nothing;" all he has is "wandering through a shapeless black void" (Rich 2013: 264). What's disconcerting about his embrace of a solitary version of Elsa's utopian vision of a "self-sufficient habitat" (Rich 2013: 280) is that his decision does not arise from a newly found insight into nature of human life on planet Earth but from a redirection of his isolating old obsessions toward something else that arguably is covered up in a more pleasant garb.

That is exactly the reason why the nostalgia of his good old fears, his "All-Consuming Passion," begin to gnaw at him in the wilderness. If the fears and the cockroaches are not here, the only thing he is left with is "void" (Rich 2013: 265). Therefore, what he in essence does is replacing one religion for another: "He had forsaken the cult of fear, had abandoned the order of the futurists. For what was obsession anyway but a kind of intense faith? Yes, a new faith was required, something rigorous, ascetic, all-encompassing" (Rich 2013: 280). His math, calculations, and "x- and y-axes" give him "boundaries" buffering the "chaos" (Rich 2013: 278). However, he realizes that he needs to pepper the order with a little bit of chaotic new faith in the semblance of "Ticonderoga" as "if he couldn't find one, then all he had was order order order order order order order order order order order order order order order order order order" (Rich 2013: 280). However, finding this very balance between chaos and order is what proves to be rather demanding for Mitchell.

What is interesting is that Rich in fact does a quite curious balancing of his own in the story he is telling. As it turns out, the roles of Elsa and Mitchell are reversed by the end of the novel as if nothing much has changed. Jane gives Mitchell an envelope from Elsa. Mitchell finds a postcard in the envelope that he had previously sent to Elsa. The postcard reads: "By the time you get this, I'll be a futurist" (Rich 2013: 303). He then notices the signature: "Only Elsa had crossed out Mitchell's name and signed her own” (Rich 2013: 303). Elsa has finally opted for a solution that would bring some predictability and stability to her existence in effect distancing herself from her "blind limbo" (Rich 2013: 201): She undergoes an "open-heart surgery to implant an automatic cardiac defibrillator - a device that carried a number of risks, but seemed necessary given the alternative" (Rich 2013: 302). She also gets into Stanford to study "environmental law," and finally lands a job at an "environmental law firm" (Rich 2013: 302). The news of such drastic change in lifestyle is quite puzzling to Mitchell: "The look on Mitchell's face was a mixture of befuddlement and high skepticism" (Rich 2013: 302). Opposed to Jane, Mitchell abandons his job in the city at its very peak 


\section{Parisa Changizi}

moment when he stands to profit substantially to go conduct his own "Walden" experiment in the wilderness.

The responses of the protagonist and the other two main characters of the novel are quite revealing. After the initial "zoo" and "war"-like situation where people are "defecating in the middle of the road" (Rich 2013: 228-229), things settle down enough for everyone to reflect upon what has happened, and how they can proceed with the lives. The fearful Mitchell, along with a number of other people, is so affected by the Hurricane that he decides to abandon his parasitic life to start a new one in the wilderness. He needs "some pursuit more vast and profound than fear prediction" (Rich 2013: 253) to feel the void of his previous life now lost to him. To him, there has "to be something larger up ahead, because if not, then the only thing was destruction and chaos" (Rich 2013: 253). "The effect of the successful adventure of the hero," as Joseph Campbell explains, "is the unlocking and release again of the flow of life into the body of the world" (2008: 40). Mitchell's adventure evidently does not result in such grand final outcome. The idealistic Elsa who has already attempted a self-sufficient, eco-friendly commune abandons her romantic plans for a more pragmatic lifestyle, one that the former Mitchell would have understood better. In effect, no one is left to idealize the agrarian toil and honest labor of her former simplistic lifestyle. And the opportunistic Jane, though almost seduced by the Mitchell's new-found lifestyle, moves to capitalize on the chaos replacing their former boss, Charnoble. In the grand scheme of things, one is left to wonder, has much changed for the better?

\section{Move Outside the Tangle of Fear-Thinking. Live in Silence: Conclusion}

Following the traditional three-stage plot sequence, apocalyptic stories are usually tempered with the anthropocentric desire for survival. An absolute tragic conception of the end of the world, though bearing much needed humility, goes against the desire of the selfish gene, borrowing from Richard Dawkins, to replicate itself. The authenticity of absolute apocalyptic stories is undermined by the very fact that they presume an audience even if they do not include witness survivors. Nonetheless, visions of utter hopelessness do exist, and more and more, we are wondering if the continuation of existence is indeed probable. Complimentary, if not the driving force, to these utterly dark visions is the ever-increasing frequency with which we wallow in apocalyptic scenarios since the end of the WWII. Odds Against Tomorrow proves to be truly a story of its times. The novel, dealing with the most common apocalyptic fears of the contemporary age, begins its journey by grappling with the wisdom (or lack thereof) of a culture alarmingly drenched in fear and acutely obsessed with risk-aversion. Then it evolves into an eco-apocalyptic story, if we are to take New York City as a stand-in for the whole of human civilization, and ends with a serious inquiry of the possibility of meaningful growth and renewal on a considerable scale following the rupture as manifested by the disparate responses of the characters in the aftermath of Seattle Earthquake, and more importantly, Hurricane Tammy. 


\section{Notes}

1 Edward F. Edinger, in his Archetype of the Apocalypse: A Jungian Study of the Book of Revelation, maintains that the apocalyptic literature exhibits four chief features:

"1) Revelation; 2) Judgment; 3) Destruction or Punishment (as the consequence of Judgement); and then 4) Renewal in a New World" (1999: 3).

2 The books include: Bloch, Joshua (1952) On the apocalyptic in Judaism. Philadelphia: Dropsie College for Hebrew and Cognate Learning. Frost, Stanley Brice (1952) Old Testament Apocalyptic: Its Origins and Growth. London: Epworth Press. Rowley, Harold Henry (1963) The relevance of apocalyptic: A study of Jewish and Christian apocalypses from Daniel to the Revelation. London: Lutterworth Press. Russell, David S. (1971) The Method and Message of Jewish Apocalyptic. London: SCM Press. Koch, Klaus (1972) The Rediscovery of Apocalyptic: A Polemical Work on a Neglected Area of Biblical Studies and its Damaging Effects on Theology and Philosophy. Trans. M. Kohl. London: SCM Press. Morris, Leon (1972) Apocalyptic. Grand Rapids, Michigan: Wm. B. Eerdmans Publishing Company. Schmithals, Walter (1975) The apocalyptic movement: Introduction $\mathcal{E}$ interpretation. Trans. John E. Steely. Nashville, Tennessee: Abingdon Press. Russell, David S. (1978) Apocalyptic: Ancient and Modern. London: SCM Press. Hanson, Paul D. (1979) The Dawn of Apocalyptic: The Historical and Sociological Roots of Jewish Apocalyptic Eschatology. Revised Edition. Philadelphia: Fortress Press. Rowland, Christopher (1982) The Open Heaven: A Study of Apocalyptic in Judaism and Early Christianity. New York: The Crossroad Publishing Company. McNamara, Martin (1983) Intertestamental Literature. Wilmington, Delaware: Michael Glazier.

In addition to the numerous published books and essays written on this topic, a number of academic journals devoted an entire issue to apocalyptic literature: Journal for Theology and Church 6 (1969); Interpretation 25 (1971); Review and Expositor 72 (1975); Semeia 14 (1979); Ex auditu 6 (1990); Journal for Near Eastern Studies 49 (1990); Calvin Theological Journal 44 (2006).

\section{Acknowledgements}

This text is a result of the project SGS04/FF/20189 "Ecocritical Perspectives on $20^{\text {th }}$ and $21^{\text {st }}$-Century American Literature" supported by the internal grant scheme of the University of Ostrava.

\section{References}

AtKisson, Alan (2011) Believing Cassandra: An Optimist Looks at a Pessimist's World. $2^{\text {nd }}$ ed. London: Earthscan.

Atwood, Margaret (2014) Why readers and writers are so fixated with dystopian visions. Financial Times. Accessed on March 16, 2016. https://www.ft.com/content/cc4a4c26aaff-11e3-be01-00144feab7de.

Aveni, Anthony (2016) Apocalyptic Anxiety: Religion, Science, and America's Obsession with the End of the World. Boulder, Colorado: University Press of Colorado.

Beck, Ulrich (1989) On the way to the industrial risk-society? Outline of an argument. Thesis Eleven 23, 86-103.

Beck, Ulrich (2009) World at Risk. Translated by Ciaran Cronin. Cambridge: Polity Press. 


\section{Parisa Changizi}

Benjamin, Walter (1969) Illuminations: Essays and Reflections. Edited by Hannah Arendt. Translated by Harry Zohn. New York: Schocken Books.

Brown, Stephen, Jim Bell, and David Carson (1996) Apocaholics anonymous: looking back on the end of marketing. In: Brown, Stephen and Jim Bell and David Carson (ed.) Marketing Apocalypse: Eschatology, Escapology and the Illusion of the End. London: Routledge, $1-20$.

Buell, Frederick (2003) From Apocalypse to Way of Life: Environmental Crisis in the American Century. New York: Routledge.

Buell, Lawrence (1995) The Environmental Imagination: Thoreau, Nature Writing, and the Formation of American Culture. Cambridge, Massachusetts: Harvard University Press.

Campbell, Joseph (2008) The Hero with a Thousand Faces. $3^{\text {rd }}$ ed. Novato, California: New World Library.

Canavan, Gerry (2012) Hope, but not for us: ecological science fiction and the end of the world in Margaret Atwood's Oryx and Crake and The Year of the Flood. Lit: Literature Interpretation Theory 23 (2), 138-159.

Caputo, John D. (1993) Against Ethics: Contributions to a Poetics of Obligation with Constant Reference to Deconstruction. Bloomington, Indiana: Indiana University Press.

Carson, Rachel (2002) Silent Spring. Boston: Houghton Mifflin Harcourt.

Cohn, Norman (1995) How time acquired a consummation. In: Bull, Malcolm (ed.) Apocalypse Theory and the Ends of the World. Oxford: Blackwell, 21-37.

Collins, Adela Yarbro (2011) Apocalypse now: the state of apocalyptic studies near the end of the first decade of the twenty-first century. The Harvard Theological Review 104 (4), 447-457.

Curry, Alice (2013) Environmental Crisis in Young Adult Fiction: A Poetics of Earth. New York: Palgrave Macmillan.

Dixon, Wheeler W. (2003) Visions of the Apocalypse: Spectacles of Destruction in American Cinema. London: Wallflower Press.

Douglas, Mary (1966) Purity and Danger: An Analysis of the Concepts of Pollution and Taboo. London: Routledge.

Edinger, Edward F. (1999) Archetype of the Apocalypse: A Jungian Study of the Book of Revelation. Edited by George F. Elder. Chicago: Open Court.

Estok, Simon C. (2013) Terror and ecophobia. Frame 26 (2), 87-100.

Farand, Chloe (2018) Extinction rebellion eyes global campaign. Ecologist, November 23. Accessed on April 27, 2019. https://theecologist.org/2018/nov/23/extinction-rebellion-eyes-global-campaign.

Fava, Sergio (2013) Environmental Apocalypse in Science and Art: Designing Nightmares. New York: Routledge.

Fortunati, Vita (1993) The metamorphosis of the apocalyptic myth: from utopia to science fiction.” In: Kumar, Krishan and Stephen Bann (ed.) Utopias and the Millennium. London: Reaktion Books, 81-89.

Garrard, Greg (2012) Ecocriticism: The New Critical Idiom. London: Routledge.

Glassner, Barry (2009) The Culture of Fear: Why Americans are Afraid of the Wrong Things. New York: Basic Books.

Gottschall, Jonathan (2012) The Storytelling Animal: How Stories Make Us Human. New York: Houghton Mifflin Harcourt.

Hamilton, Edith (1942) Mythology. New York: Little, Brown and Company.

Joyce, Stephen (2018) Transmedia Storytelling and the Apocalypse. Cham, Switzerland: Springer Nature.

Jung, Carl Gustav (1976) The Collected Works of C. G. Jung: Symbols of Transformation. $2^{\text {nd }}$ ed. Edited by Herbert Read, Michael Fordham and Gerhard Adler. Translated by R.F.C. Hull. Vol. V. Princeton, New Jersey: Princeton University Press. 
Kermode, Frank (2000) The Sense of an Ending: Studies in the Theory of Fiction. New York: Oxford.

Killingsworth, M. Jimmie, and Jacqueline S. Palmer (1996) Millennial ecology: the apocalyptic narrative from Silent Spring to Global Warming. In: Herndl, Carl G. and Stuart C. Brown (ed.) Green Culture: Environmental Rhetoric in Contemporary America. Madison, Wisconsin: University of Wisconsin Press, 21-45.

Lomborg, Bjørn (2019) It's cheaper to talk than to cut emissions. Project Syndicate, May 17. Accessed on 5 25, 2019. https://www.lomborg.com/news/its-cheaper-to-talk-than-tocut-emissions.

Mehnert, Antonia (2016) Climate Change Fictions: Representations of Global Warming in American Literature. London: Palgrave Macmillan.

Mental Health and Our Changing Climate: Impacts, Implications, and Guidance. American Psychological Association 1-70. Accessed on February 28, 2021.

Mill, John Stuart (1873) On perfectibility. In: Autobiography. London: Geoffrey Cumberlege, Oxford University Press, 288-309.

Moore, Bryan L. (2017) Ecological Literature and the Critique of Anthropocentrism. Jonesboro, AR: Palgrave Macmillan.

Moore, Hamilton (1986) The problem of apocalyptic as evidenced in recent discussion. IBS 13, 77-91.

Nesse, Randolph, and George Williams (1997) Are mental disorders diseases? In: Baron-Cohen, Simon (ed.) The Maladapted Mind: Classic Readings in Evolutionary Psychopathology. Hove, East Sussex: Psychology Press, 1-22.

Northover, Richard Alan (2016) Ecological apocalypse in Margaret Atwood's MaddAddam Trilogy. Studia Neophilologica 88 (Sup1), 81-95.

Oxford Student (2019) Oxford professor argues invisible aliens are interbreeding with humans. April 26. Accessed on April 28, 2019. https://www.oxfordstudent. com/2019/04/26/oxford-professors-theory-on-climate-change-and-alien-abduction/

Rich, Nathaniel (2013) Odds Against Tomorrow: A Novel. New York: Farrar, Straus and Giroux.

Russell, David S. (1978) Apocalyptic: Ancient and Modern. London: SCM Press.

Schwartz, Hillel (2011) The escathology of everyday things, England 1600-1800. In: Force, James E. and Richard H. Popkin (ed.) The Millenarian Turn: Millenarian Contexts of Science, Politics, and Everyday Anglo-American Life in the Seventeenth and Eighteenth Centuries. Millenarianism and Messianism in Early Modern European Culture: Volume III. Dordrecht: Kluwer Academic Publishers, 171-180.

Siegel, Marc (2005) False Alarm: The Truth about the Epidemic of Fear. Hoboken, New Jersey: Wiley.

Sinclair, Upton (1994) I, Candidate for Governor: And How I Got Licked. Berkeley: University of California Press.

Stephens, Elizabeth M., and Annie M. Sprinkle. n.d. Ecosex manifesto. Accessed on April 24, 2019. http:/ /sexecology.org/research-writing/ecosex-manifesto/

Thunberg, Greta (2019) 'Our house is on fire': Greta Thunberg, 16, urges leaders to act on climate. The Guardian, January 25. Accessed February 25, 2021. https://www.theguardian.com/environment/2019/jan/25/our-house-is-on-fire-greta-thunberg16-urgesleaders-to-act-on-climate.

Tupper, E. Frank (1975) The revival of apocalyptic in biblical and theological studies. RevExp 72 (3): 279-303.

Vagianos, Alanna (2019) 16-year-old climate activist Greta Thunberg nominated for Nobel Peace Prize. Huffpost, March 14. Accessed on April 27, 2019. https://www.huffpost.com/ entry/climate-activist-greta-thunberg-nobel-peace-prize_n_5c8a4ab8e4b0fbd7662145a4. 


\section{Parisa Changizi}

Weber, Samuel (2015) Foreword: One sun too many. In: Szendy, Peter (ed.) Apocalypse-cinema: 2012 and Other Ends of the World, translated by Will Bishop. New York: Fordham University Press, ix-xx.

Weissmann, Jordan (2019) What the Christchurch killer's manifesto tells us. Slate, March 15. Accessed on April 28, 2019. https://slate.com/news-and-politics/2019/03/what-thechristchurch-attackers-manifesto-tells-us.html.

White, E. B. (2011) Here is New York. reprint. New York: The Little Bookroom.

Wojcik, Daniel N. (1997) The End of the World As We Know It: Faith, Fatalism, and Apocalypse in America. New York: NYU Press.

Yedroudj, Latifa (2019) Oxford university teacher says aliens are already breeding with humans on earth. Mirror, April 27. Accessed on April 28, 2019.

Žižek, Slavoj (2011) Living in the End Times. London: Verso.

Parisa Changizi previously received her Ph.D. from Shiraz University, Iran where she defended her dissertation entitled "An Ecocritical Study of Selected Works of Margaret Atwood" in 2017. In her research, with an eye to the intersections of race, gender, and environment, she studied the selected novels from an environmental perspective that has burrowed its way across postcolonial and feminist frameworks. She is now pursuing her second Ph.D. majoring in English and American Literature at University of Ostrava, Czech Republic. She is currently working on her dissertation entitled "Visions of the End: Eco-Apocalypse in Contemporary American Literature." The main focus of her research is on (eco)apocalyptic rhetoric and environmental fear.

Address: Parisa Changizi, Department of English and American Studies, Faculty of Arts, University of Ostrava, Ostrava, Czech Republic. [email: parisa.changizi@osu.cz] 